\title{
Study of the Training Accreditation in a Moroccan Engineering School: Strengths, Weaknesses, Opportunities and Threats
}

\author{
Zhor Ouzzine $^{1}$, Souad Ajana ${ }^{1}$, Soumia Bakkali ${ }^{1} \&$ Imane Msitef $^{1}$ \\ ${ }^{1}$ Research Team on Engineering Sciences Education, Engineering Research Laboratory, National Higher School of \\ Electricity and Mechanics, Hassan II University, Casablanca, Morocco \\ Correspondence: Zhor Ouzzine, Research Team on Engineering Sciences Education, Engineering Research \\ Laboratory, National Higher School of Electricity and Mechanics, Hassan II University, Casablanca, Morocco
}

Received: December 17, 2019

Accepted: February 4, 2020

Online Published: February 6, 2020

doi:10.5430/ijhe.v9n2p225

URL: https://doi.org/10.5430/ijhe.v9n2p225

\begin{abstract}
This research paper aims to improving engineering training quality in Morocco with a special focus on the learning outcomes assessment.

To achieve the purpose of this study, we reviewed the different accreditation related to the Higher National School of Electricity and Mechanics (ENSEM) between 2007 and 2018. The data was gathered from the Mechanical Design and Integrated Production branches (CMPI) and we considered it using the SWOT decision-making method.

We then compared the CMPI program to a list of learning outcomes chosen after conducting a benchmarking analysis.

The present research aims at highlighting the strengths and weaknesses of the Moroccan engineering accreditation system, especially regarding the learning outcomes. The findings of this examination provide some implications to improve the quality of engineering training, specifically the assessment of learning to enable the Moroccan diplomas to align with the international standards and meet the great challenges facing globalization.
\end{abstract}

Keywords: quality, engineers training, accreditation, SWOT, learning outcomes, evaluation

\section{Introduction}

Performance has become omnipresent in all spheres of human activity, including engineering training.

The Commission of Engineering Titles (CTI) in France defines the role of an engineer as follows:

"The job of the engineer is to introduce, study, and solve out, in an innovative and efficient way, complex problems related to creation, conception, realization, implementation, control—and the possible financing and marketing-of products, systems or services. It integrates the concerns of human, life and environment protection, and more generally the collective well-being (CTI, 2019)."

Due to markets internationalization, and competition intensification, companies must face the new characteristics of their surroundings (El Ouahabi \& Bousselhami, 2018). Therefore, employers require that the freshly graduated engineers be operational with a strong added value.

Nowadays, engineering training is confronted to overcrowding and globalization that fundamentally change working conditions. Thus, education institutions can no longer live on an 'island of knowledge'; they must exchange, evolve, and open up, etc. (LEMENU \& HEINEN, 2015).

Many processes and agreements have emerged at international level. We can mention, the Bologna Process (European Commission, 2019), the Washington Accord and the Sydney Accord (International Engineering Alliance, 2019). Several accreditation bodies that ensure the quality of engineering education programs have also been established. Some examples to cite are the Accreditation Board for Engineering and Technology (ABET) for the U.S.A., Engineers Australia, Engineering Title Commission (CTI) for France, Canadian Engineering Accreditation Board (CEAB) etc.

These changes have led to substantial reforms in engineering training, including the move to the competency-based approach, then to learning outcomes (LEMENU \& HEINEN, 2015). A learning outcome is the statement of what the student must understand and be able to achieve at the end of a course or a validated unit. It's defined in terms of 
knowledge, skills, and abilities (Communauté française, 2013).

In Morocco, the Bologna process started to be applied almost by the time it began in Europe. Indeed, the Moroccan government decided in the early 2000s to improve its higher education system thanks to it (LMD reform, new public management, evaluation of research, etc.). The goal is to upgrade these teaching systems, to professionalize some diplomas, and to initiate a quality assurance strategy (Ghouati, 2010).

However, the application of the Bologna process for selective disciplines, such as engineering training, only started in 2006-2007 (Ghouati, 2010). The approach enhanced the training programs through the accreditation that are renewed every four or five years and re-adapted according to the Moroccan market and to earlier conducted studies (ENSEM, 2007, 2011, 2015, 2018). But, despite all the achieved progress to improve engineering training, the Moroccan engineering degree is still not recognized internationally. Indeed, young Moroccan graduates wishing to work abroad can only have a job if they carry out additional training to obtain diploma equivalence.

The reforms of the higher educational system have concluded that pedagogy must be centered on the learning process rather than on the content to be taught. Besides imparting knowledge or applying skills, students must develop the capacity of analyzing situations, identifying and using in an integrated way the relevant internal and external resources to solve them. Indeed, the shift to a program approach, based on learning outcomes, can quickly focus exclusively on the development of professional abilities established on solid and effective aptitudes. Therefore, learning outcomes appears as the link between the expectations of society (the competence repositories) and the educational institution (LEMENU \& HEINEN, 2015).

The starting point of this research was an inventory of the accreditation system in Morocco. We evaluated and compared the accreditation carried out in ENSEM since 2007 using the SWOT decision-making method. This comparison shed light on the points to improve for an appropriate accreditation procedure that allows the Moroccan engineering training to align with the international scale.

A benchmarking study of the different learning outcomes that are set up by international certification bodies allowed choosing the appropriate repository as a reference for the case study of this research.

Finally, we examined the training programs in the last Moroccan accreditation, and we compared them to the learning outcomes set up by the chosen repository to highlight those to be implemented in engineering schools in Morocco.

\section{Research Questions and Methodology}

The goal of this research paper is to examine the following research questions:

- What constitutes the opportunities to seize for the accreditation of engineering courses in Morocco and what are the threats that should be avoided?

- Which learning outcomes do exist in the Moroccan engineering training and which ones are to be implemented?

The study is based on a comparative conceptual approach. The decision-making methods and the benchmarking study allowed us to select the most appropriating elements for our context through the analysis of standards and certification specifications at national and international levels.

\section{Study of the Engineering Training's Accreditation at ENSEM}

In 2007, Morocco introduced the standards for the accreditation of training in engineering schools; however, the criteria definition remains unclear and the norms don't specify the learning outcomes to fulfill. Every syllabus identifies its objectives for each subject or section (ENSEM, 2007, 2011, 2015, 2018).

Indeed, for a course to be accredited, the coordinator must complete the application, including the number of modules for each unit with their descriptions, the hourly volume, and the skills to acquire. These descriptions must follow the Pedagogical Standards Booklet published in the Moroccan Official Bulletin (CNASES, 2014).

The focus of the present study is on the national accreditation in Moroccan engineering schools and more precisely at ENSEM. The collected data was taken from the Mechanical Design and Integrated Production (CMPI) branch for the three sessions 2007, 2011 and 2015 (ENSEM, 2007, 2011, 2015, 2018).

\subsection{Comparative Study of the CMPI Training Accreditation}

This research analysis is based on the SWOT decision-making method (Strengths, Weaknesses, Opportunities and Threats) that was developed by four professors from Harvard in order to identify the strengths and weaknesses of an organization or a project in the light of the external environment opportunities, and threats (Besson \& Al., 2010). 
The study refers to the specifications for accreditation of the Commission for Engineering Titles in France (CTI) to select the criteria for the engineer's training (CTI, 2016). This is justified by the existing similarity between the Moroccan and the French teaching strategies.

All these requirements have been formalized into 13 criteria to be used to study the accreditation of the CMPI program.

This analysis allowed drawing up a comparative framework.

These following scales have been opted for:

- Highly: Integration of the criterion between $75 \%$ and $100 \%$.

- Moderately: Integration of the criterion between $50 \%$ and $74 \%$.

- Weakly: Integration of the criterion between $25 \%$ and $49 \%$.

- No: Integration of the criterion less than $25 \%$.

The results of this analysis are presented in Table 1.

Table 1. Comparative study of CMPI* accreditation between 2007 and 2019

\begin{tabular}{|c|c|c|c|c|}
\hline $\begin{array}{c}\text { Comparison } \\
\text { Criterion }\end{array}$ & & Designation & $\begin{array}{l}2007-2011^{* *} \\
\text { Accreditation }\end{array}$ & $\begin{array}{l}2015 \text { Accreditation } \\
\text { (amendment 2018)*** }\end{array}$ \\
\hline Criterion 1-A & -Openings and & -At a national level & Highly & Highly \\
\hline Criterion 1-B & partnerships & -At an international level & Moderately & Moderately \\
\hline Criterion 1-C & & -With companies & Highly & Highly \\
\hline Criterion 1-D & & -With the research & No & No \\
\hline Criterion 2-A & $\begin{array}{l}\text {-Considering the } \\
\text { economic }\end{array}$ & $\begin{array}{c}\text {-National, international and local } \\
\text { environment }\end{array}$ & Weakly & Moderately \\
\hline Criterion 2-B & $\begin{array}{c}\text { environment while } \\
\text { developing and } \\
\text { monitoring } \\
\text { training }\end{array}$ & $\begin{array}{l}\text {-Study of the areas and/or jobs } \\
\text { targeted future needs }\end{array}$ & No & No \\
\hline Criterion 3 & $\begin{array}{c}\text {-Training } \\
\text { standardization }\end{array}$ & $\begin{array}{l}\text {-Learning outcomes are } \\
\text { subdivided into knowledge, skills, } \\
\text { general and specific competences } \\
\text { regarding the business reference } \\
\text { frameworks }\end{array}$ & Weakly & Moderately \\
\hline Criterion 4 & $\begin{array}{l}\text {-Consistency of the } \\
\text { curriculum with } \\
\text { the skills sought }\end{array}$ & $\begin{array}{l}\text {-Link between each module } \\
\text { (subject) and the skills established }\end{array}$ & Weakly & Moderately \\
\hline Criterion 5 & $\begin{array}{l}- \text { Structure of } \\
\text { in-company } \\
\text { training } \\
\text { (traineeship) }\end{array}$ & $\begin{array}{l}\text {-Acquired skills in the company } \\
\text { described, specified and evaluated }\end{array}$ & Moderately & Highly \\
\hline Criterion 6 & $\begin{array}{c}\text {-Existence of } \\
\text { innovation and } \\
\text { entrepreneurship } \\
\text { training }\end{array}$ & $\begin{array}{l}\text {-The Opening on innovation and } \\
\text { the creation of an activity or } \\
\text { company }\end{array}$ & No & Weakly \\
\hline Criterion 7-A & -Consideration of & -English & Highly & Highly \\
\hline Criterion 7-B & $\begin{array}{l}\text { language } \\
\text { proficiency }\end{array}$ & -Required minimum level & No & No \\
\hline Criterion 8-A & -International & -Receiving foreign students & No & No \\
\hline Criterion 8-B & stu & $\begin{array}{l}\text {-An Outgoing international } \\
\text { movement of engineering students }\end{array}$ & Moderately & Moderately \\
\hline
\end{tabular}




\begin{tabular}{|c|c|c|c|c|}
\hline Criterion 9-A & \multirow{3}{*}{$\begin{array}{l}\text {-Emphasis on the } \\
\text { concepts of } \\
\text { sustainable } \\
\text { development, } \\
\text { social } \\
\text { responsibility, } \\
\text { ethics and } \\
\text { deontology (in a } \\
\text { cross-cutting } \\
\text { manner) }\end{array}$} & -Sustainable development & Weakly & Moderately \\
\hline Criterion 9-B & & -Social responsibility & No & Weakly \\
\hline Criterion 9-C & & -Ethics \& Deontology & No & Weakly \\
\hline Criterion 10-A & $\begin{array}{l}\text {-Developing a } \\
\text { pedagogy suitable } \\
\text { to the objectives }\end{array}$ & $\begin{array}{l}\text {-Teaching combines traditional } \\
\text { methods with problems or } \\
\text { project-based learning situations }\end{array}$ & Moderately & Highly \\
\hline Criterion 10-B & $\begin{array}{l}\text { and the training } \\
\text { path }\end{array}$ & $\begin{array}{l}\text {-Providing a significant amount of } \\
\text { training time by specialists from } \\
\text { the business world }\end{array}$ & No & Weakly \\
\hline Criterion 11-A & $\begin{array}{l}\text {-Review of the } \\
\text { results obtained by }\end{array}$ & -Verifying the results & No & No \\
\hline Criterion 11-B & $\begin{array}{l}\text { students and } \\
\text { ensuring }\end{array}$ & -Follow-up and support & No & No \\
\hline & $\begin{array}{l}\text { a customized } \\
\text { follow-up and } \\
\text { support }\end{array}$ & & & \\
\hline Criterion 12-A & $\begin{array}{l}\text {-Defining the } \\
\text { evaluation method }\end{array}$ & -If possible with companies & No & No \\
\hline Criterion 12-B & & $\begin{array}{l}\text {-Based on previously defined and } \\
\text { publicly accessible criteria }\end{array}$ & Weakly & Weakly \\
\hline Criterion 13-A & $\begin{array}{l}\text {-Preparation for } \\
\text { employment of the }\end{array}$ & $\begin{array}{l}\text {-Information and advice system } \\
\text { on careers for students }\end{array}$ & Moderately & Moderately \\
\hline Criterion 13-B & graduates & $\begin{array}{l}\text {-Promoting guidance and job } \\
\text { readiness }\end{array}$ & No & Weakly \\
\hline Criterion $13-\mathrm{C}$ & & $\begin{array}{l}\text {-Promoting the implementation of } \\
\text { activities and supporting the } \\
\text { engineering students concerned }\end{array}$ & No & No \\
\hline
\end{tabular}

* CMPI: branch attached to the mechanical engineering department; among the oldest at ENSEM with a strategic place in the Moroccan industrial sector.

**The 2007 accreditation was reestablished in 2011 with minimal revisions (fewer than $20 \%$ changes in the program).

*** During the accreditation period, it's possible to modify up to $20 \%$ of the modules and their content with amendments. We studied the 2018 version which is in force and will renew in 2020.

The analysis in the table 1 allows us to realize the histogram shown in Figure 1. 


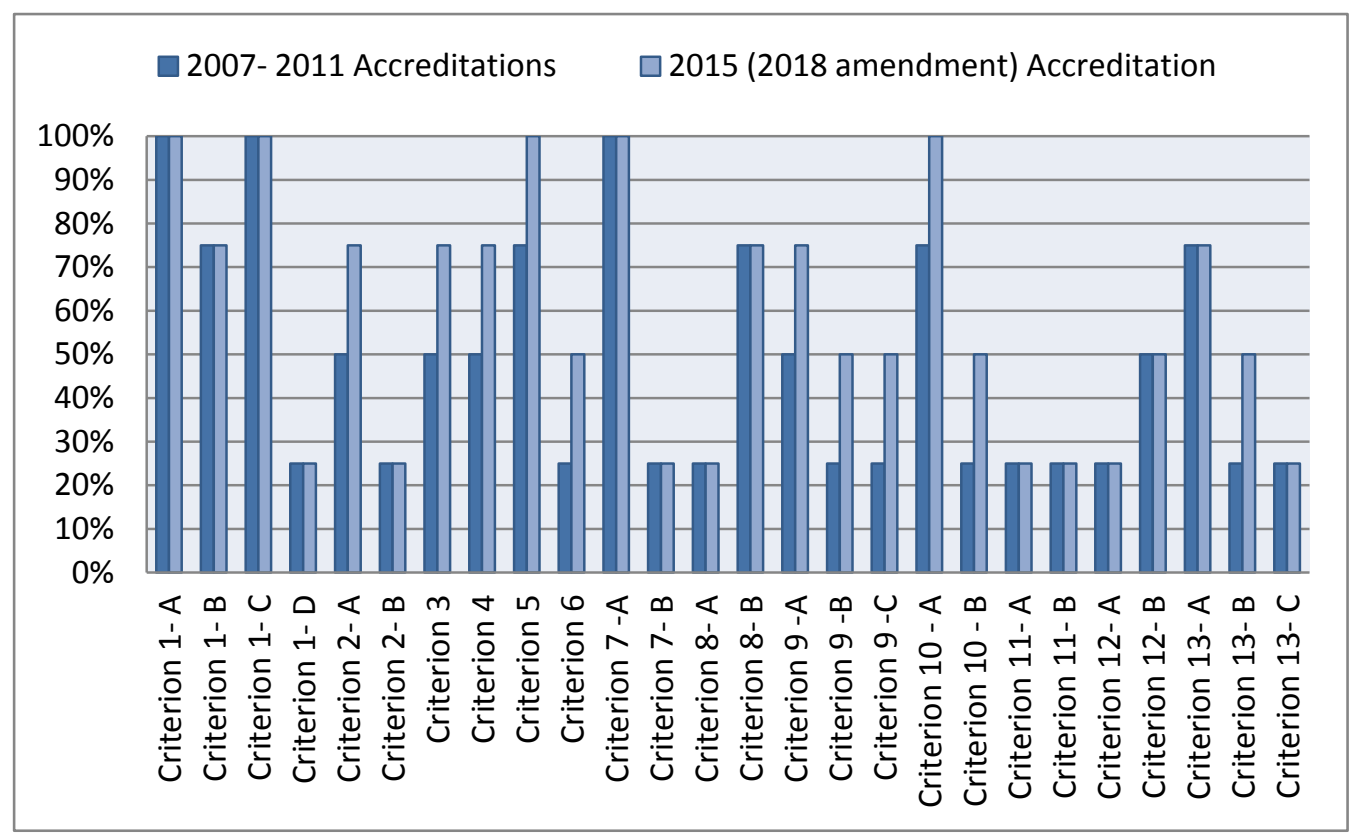

Figure 1. Comparison of 2007-2011 and 2015 (Amendment 2018) accreditation.

Figure 1 shows that the 2015 accreditation, specifically the 2018 amendment, better meets the criteria. Indeed, the evolution of several points is very noticeable. Some examples to cite are openness, partnerships and the structure of in-company training. Generally, we note that the number of highly or moderately included aspects has increased from 8 in the 2007 accreditation to 12 in the 2018 amendment.

It is worth mentioning that many elements need improvement such as considering the economic environment when developing, and monitoring teaching or honoring notions of social responsibility, deontology and ethics. Indeed, figure 1 above shows that the proportion of non-integrated criteria went from 13 in 2007 accreditation to 8 in 2018 amendment.

The study of the different certifications allows the realization of the internal approach of the SWOT analysis to highlight the CMPI training strengths and weaknesses.

\subsection{SWOT Analysis}

In the SWOT examination, strengths constitute the positive elements that the organization handles and could employ in the future. Otherwise, weaknesses represent the negative internal aspects that are controlled by the organization and that have a significant margin for improvement. Table 2 outlines the internal procedure of the SWOT method.

Table 2. Internal approach of SWOT analysis

\begin{tabular}{|c|c|c|c|}
\hline \multicolumn{4}{|c|}{ Internal approach } \\
\hline $\begin{array}{l}\text { Comparison } \\
\text { criterion }\end{array}$ & List of strengths & List of weaknesses & $\begin{array}{l}\text { Evaluate how strengths help to } \\
\text { control weaknesses }\end{array}$ \\
\hline $\begin{array}{l}\text { Criterion } 1 \\
\text { (A-B-C-D) }\end{array}$ & $\begin{array}{c}\text {-Training has openings and } \\
\text { partnerships with companies, at } \\
\text { national and at international } \\
\text { levels. }\end{array}$ & $\begin{array}{l}\text {-Training has no openness and } \\
\text { partnership with research. }\end{array}$ & $\begin{array}{l}\text {-Partnerships with international } \\
\text { universities can help create } \\
\text { alliances with research } \\
\text { laboratories related to these } \\
\text { universities. }\end{array}$ \\
\hline $\begin{array}{l}\text { Criterion } 2 \\
\quad(\mathrm{~A}-\mathrm{B})\end{array}$ & $\begin{array}{l}\text {-Training development considers } \\
\text { the economic environment. }\end{array}$ & $\begin{array}{l}\text {-Development and monitoring of } \\
\text { training don't enough analyze the } \\
\text { future requirements of the sectors } \\
\text { and/or trades. }\end{array}$ & $\begin{array}{l}\text {-Study on the current need } \\
\text { possibly extended if necessary } \\
\text { over the long or medium term } \\
\text { by projecting in the future. }\end{array}$ \\
\hline Criterion 3 & $\begin{array}{l}\text {-Training objectives specified for } \\
\text { each module. }\end{array}$ & $\begin{array}{l}\text {-Objectives not declined into } \\
\text { learning outcomes, knowledge, }\end{array}$ & $\begin{array}{l}\text {-Objectives represent a first } \\
\text { basis to study to obtain the }\end{array}$ \\
\hline
\end{tabular}




\begin{tabular}{|c|c|c|c|}
\hline & & capacities and skills. & $\begin{array}{l}\text { learning outcomes, knowledge, } \\
\text { skills and competences. }\end{array}$ \\
\hline Criterion 4 & & $\begin{array}{l}\text {-Links between the elements of } \\
\text { the module and the skills needed } \\
\text { not always explicitly established. }\end{array}$ & \\
\hline Criterion 5 & $\begin{array}{c}\text {-Effectively structured } \\
\text { In-company training } \\
\text { (enterprise/school } \\
\text { co-supervision), skills acquired } \\
\text { well evaluated (report + } \\
\text { presentation). }\end{array}$ & $\begin{array}{l}\text {-Skills to acquire in companies } \\
\text { neither described nor specified to } \\
\text { students. }\end{array}$ & $\begin{array}{l}\text {-Skills to acquire in companies } \\
\text { should be discussed with } \\
\text { industrial administrators and } \\
\text { detailed to students. }\end{array}$ \\
\hline Criterion 6 & $\begin{array}{l}\text {-Existing training on the } \\
\text { companies and their functioning }\end{array}$ & $\begin{array}{c}\text {-Lack of training on innovation } \\
\text { and business or enterprise } \\
\text { creation. }\end{array}$ & $\begin{array}{l}\text {-Introduce and strengthen the } \\
\text { innovation and creation of } \\
\text { activity part in the } \\
\text { company-functioning training. }\end{array}$ \\
\hline $\begin{array}{l}\text { Criterion } 7 \\
\quad(\mathrm{~A}-\mathrm{B})\end{array}$ & $\begin{array}{c}\text {-English language teaching } \\
\text { represents } 6 \% \text { of the hourly } \\
\text { number. }\end{array}$ & -No minimum level required. & $\begin{array}{l}\text {-In 2015, the course information } \\
\text { uses TOEIC (Test of English for } \\
\text { International Communication) } \\
\text { manuals, it should be interesting } \\
\text { to take a minimum level from } \\
\text { these tests. }\end{array}$ \\
\hline $\begin{array}{l}\text { Criterion } 8 \\
\text { (A-B) }\end{array}$ & $\begin{array}{l}\text {-Outgoing international mobility } \\
\text { of engineering students is on the } \\
\text { rise between } 2010 \text { and } 2019 .\end{array}$ & $\begin{array}{l}\text {-No reception of foreign students } \\
\text { (in the context of mobility). }\end{array}$ & \\
\hline $\begin{array}{l}\text { Criterion } 9 \\
(\mathrm{~A}-\mathrm{B}-\mathrm{C})\end{array}$ & $\begin{array}{l}\text {-Projects and days dedicated to } \\
\text { sustainable development } \\
\text { organized outside the course } \\
\text { programs. }\end{array}$ & $\begin{array}{c}\text {-Concepts of social } \\
\text { responsibility, ethics and } \\
\text { deontology aren't taught enough. }\end{array}$ & \\
\hline $\begin{array}{l}\text { Criterion } 10 \\
\quad(\mathrm{~A}-\mathrm{B})\end{array}$ & $\begin{array}{l}\text {-Teaching combines traditional } \\
\text { methods with problems or } \\
\text { project-based learning situations. }\end{array}$ & $\begin{array}{l}\text {-Training delivered exclusively } \\
\text { by teachers with no instruction } \\
\text { given by business world } \\
\text { professionals. }\end{array}$ & \\
\hline $\begin{array}{l}\text { Criterion } 11 \\
\text { (A-B) }\end{array}$ & & $\begin{array}{l}\text {-Training doesn't verify the } \\
\text { results obtained by engineering } \\
\text { students nor provide personalized } \\
\text { follow-up and support. }\end{array}$ & \\
\hline $\begin{array}{l}\text { Criterion } 12 \\
\quad \text { (A-B) }\end{array}$ & & $\begin{array}{l}\text {-Evaluation method not defined } \\
\text { with companies nor based on } \\
\text { criteria previously determined } \\
\text { and publicly attainable. }\end{array}$ & \\
\hline \multirow[t]{2}{*}{$\begin{array}{l}\text { Criterion } 13 \\
(\text { A-B-C })\end{array}$} & $\begin{array}{c}\text {-Career opportunities specified in } \\
\text { the accreditation }\end{array}$ & $\begin{array}{l}\text {-No provision for career } \\
\text { information and advice for } \\
\text { students. }\end{array}$ & $\begin{array}{l}\text {-Career opportunities still need } \\
\text { to explain to students. }\end{array}$ \\
\hline & & $\begin{array}{l}\text {-Guidance and preparation for } \\
\text { employment aren't promoted, } \\
\text { neither the value of creating } \\
\text { activities and supporting } \\
\text { students. }\end{array}$ & \\
\hline
\end{tabular}

The internal process of SWOT analysis allowed highlighting the strengths, and weaknesses of the training. The study also spotlighted how to transform the weaknesses into strengths by complementing partnerships with universities, by creating research alliances or completing teaching program to obtain the learning outcomes, knowledge, skills, and competencies. 
The comparison of the different international accreditation systems and criteria allowed carrying out the external procedure of SWOT method. This phase helped highlighting opportunities and threats. Opportunities represent positive possibilities the organization can potentially utilize in the strengths and weaknesses context. On the other hand, threats constitute obstacles or constraints that can prevent or limit development.

The external approach of SWOT study is shown in table 3.

Table 3. External approach of SWOT analysis

\begin{tabular}{|c|c|c|}
\hline \multicolumn{3}{|l|}{ External Approach } \\
\hline List of threats & List of opportunities & $\begin{array}{l}\text { Examine how opportunities can } \\
\text { minimize threats }\end{array}$ \\
\hline $\begin{array}{l}\text {-Non-recognition of the laureates at } \\
\text { the international level }\end{array}$ & $\begin{array}{l}\text {-Training international accreditation } \\
\text { possibility }\end{array}$ & $\begin{array}{l}\text {-Recognition of the training } \\
\text { overseas if international } \\
\text { organizations certifies it }\end{array}$ \\
\hline $\begin{array}{l}\text {-Inadequacy between training and } \\
\text { labor market requirements }\end{array}$ & $\begin{array}{l}\text {-Accreditation renewed every four or } \\
\text { five years }\end{array}$ & $\begin{array}{l}\text {-Introduce the training targeted } \\
\text { labor market sectors current and } \\
\text { future needs study }\end{array}$ \\
\hline \multirow[t]{2}{*}{$\begin{array}{l}\text {-Laureate levels recognized as } \\
\text { insufficient by manufacturers and } \\
\text { companies }\end{array}$} & \multirow[t]{2}{*}{$\begin{array}{l}\text {-Accreditation of training according to } \\
\text { international criteria }\end{array}$} & $\begin{array}{l}\text {-Improve the assessment of } \\
\text { acquired skills to know the real } \\
\text { level of engineering students }\end{array}$ \\
\hline & & $\begin{array}{l}\text {-Establish a comprehensive } \\
\text { accreditation system and propose } \\
\text { its application at a national level }\end{array}$ \\
\hline
\end{tabular}

The external approach of SWOT analysis allowed highlighting the threats and opportunities of the engineering education. This study also spotlighted ways to turn threats into opportunities; such as certifying training internationally or studying labor market needs before each new accreditation.

The SWOT study is about ENSEM's CMPI training. The analysis was conducted with the research team members who are from the teaching staff and who actively participate in the accreditation committee of the CMPI training.

\subsection{SWOT Analysis Results}

In SWOT analysis, connecting internal and external approaches is still complex. Strengths and weaknesses can only be discussed relating to the external situation, and conversely, threats and opportunities are defined according to strengths and weaknesses. However, the two charts above served to link, on the one hand, the strengths and weaknesses to examine how the strengths would control the weaknesses and the list of threats and opportunities from another hand, so as to determine how the opportunities would minimize the threats.

The aim of the SWOT decision-making method is to briefly represent the elements that impact the success of a project. In this case study, the final goal of the inquiry consists of improving the student's knowledge evaluation. This is why, in the recapitulation of the SWOT investigation, only the strengths, weaknesses, opportunities and threats that have a direct connection with the learning outcomes and their assessment will be considered.

The figure 2 represents the summary of SWOT analysis concerning ENSEM's CMPI training accreditation. 


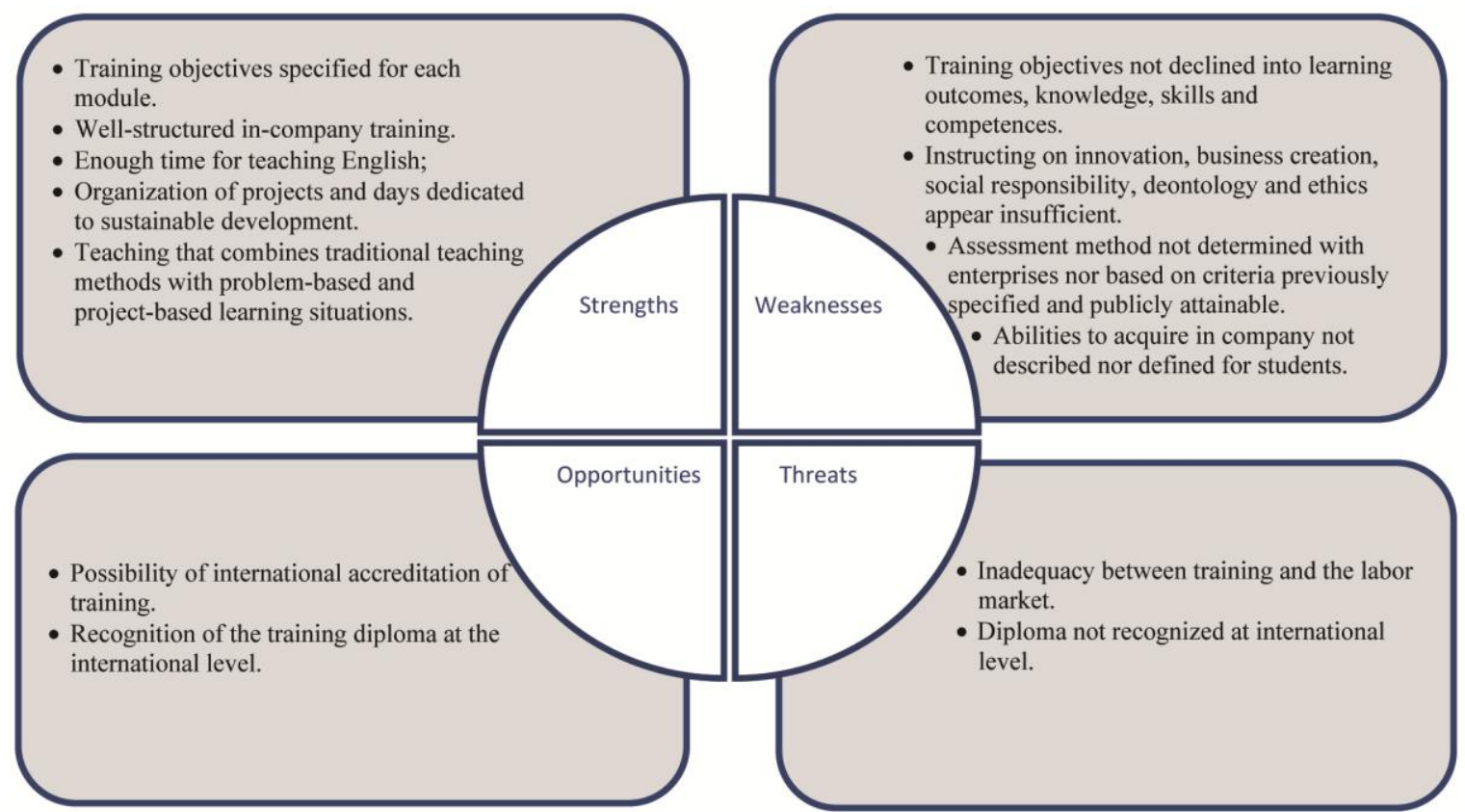

Figure 2. Summary of the SWOT analysis related to the accreditation of CMPI training at ENSEM.

The analysis of the figure 2 highlights the strengths and weaknesses of CMPI education at ENSEM.

Indeed, the efforts made during the last three accreditation allowed to enhance the level of instruction by combining the different teaching methods; by setting up new projects at school or in companies and by structuring traineeship. However, several aspects need to be improved, especially specifying each module's learning outcomes and declining them in terms of knowledge, competences and skills according to the job referential. The syllabus should include innovation, entrepreneurship, social responsibility, ethics and deontology. The assessment method should be developed, if possible with professionals from the fields targeted and based on pre-defined publicly attainable criterion.

Training can't evolve outlying from the industrial world because it's a part of an environment with influence on its actions. This environment can present threats or opportunities.

It is also identifiable that risks can hinder instruction like the inadequacy between the labor market and the program because its monitoring doesn't review the needs of the different sectors and/or careers considered for the laureates.

However, school managers can try to turn threats into opportunities. Indeed, the accreditation by foreign organizations would allow the recognition of diplomas universally.

Finally, training at ENSEM has undergone a great change, but the definition and implementation of the learning outcomes and their evaluation requires an improvement. The ones that are set up at the international level have been studied to establish a list adapted to the Moroccan context, including ENSEM.

\section{Study of the International Level Engineering Training Learning Outcomes}

This section represents a benchmarking of the learning outcomes set up by the various certification bodies at the international level. To have a broad and global vision, the organizations in the countries or groups of states listed below have been chosen:

- Accreditation Board for Engineering and technology (ABET) for the United States of America (Engineering Accreditation Commission, 2014);

- European accreditation Framework Standards (EAFS) for the European High Engineering Area (EUR-ACE) (Eugene Academic Network, n.d.);

- Engineers Australia (EA) (Engineers Australia, n.d.);

- Canadian Engineering Accreditation Board (CEAB) (Engineers Canada, 2015);

- Japan Accreditation Board for Engineering Education (JABEE) (JABEE, 2015);

- $\quad$ Accreditation Board for Engineering Education of Korea (ABEEK) (ABEEK, 2015). 
The analysis of these organization specifications helped us to compile and list the different learning outcomes required in the engineer's training curriculum. Their number and definitions vary according to the certification body.

The decision table method was opted for in order to examine and compare the data relating to our benchmarking. It's Bayes matrix that prioritizes ideas in group. The five-step process approach is choosing the criterion; settling the scoring scale; voting; collecting the results and concluding (Fourmental, n.d.).

In the first phase, we combined the learning outcomes determined by the accreditation bodies into the four types defined by Peter T. Well from the Council for Higher Education Accreditation (2001).

The latter are explained as follows:

$\checkmark$ Knowledge Outcomes represent the areas of disciplinary or professional content that students can discuss, report and, deploy appropriately.

$\checkmark$ Skills Outcomes constitute the abilities to do things acquired by the graduates, such as critical thinking or effective communication.

$\checkmark$ Affective Outcomes engage changes in beliefs or the development of values, such as empathy or ethical behavior.

Learned Abilities involve the integration of knowledge, skills and attitudes in a complex manner requiring multiple elements of learning, such as teamwork or leadership.

We used Bloom's Taxonomy levels which are respectively: knowledge, understanding, application, analysis, synthesis and evaluation (International Assembly for Collegiate Business Education, 2016) as a basis for the mark scale.

Figure 3 represents the Bloom's Taxonomy Pyramid (Paideia, 2018).

\section{$B L O O M S T A X O N O M Y$}

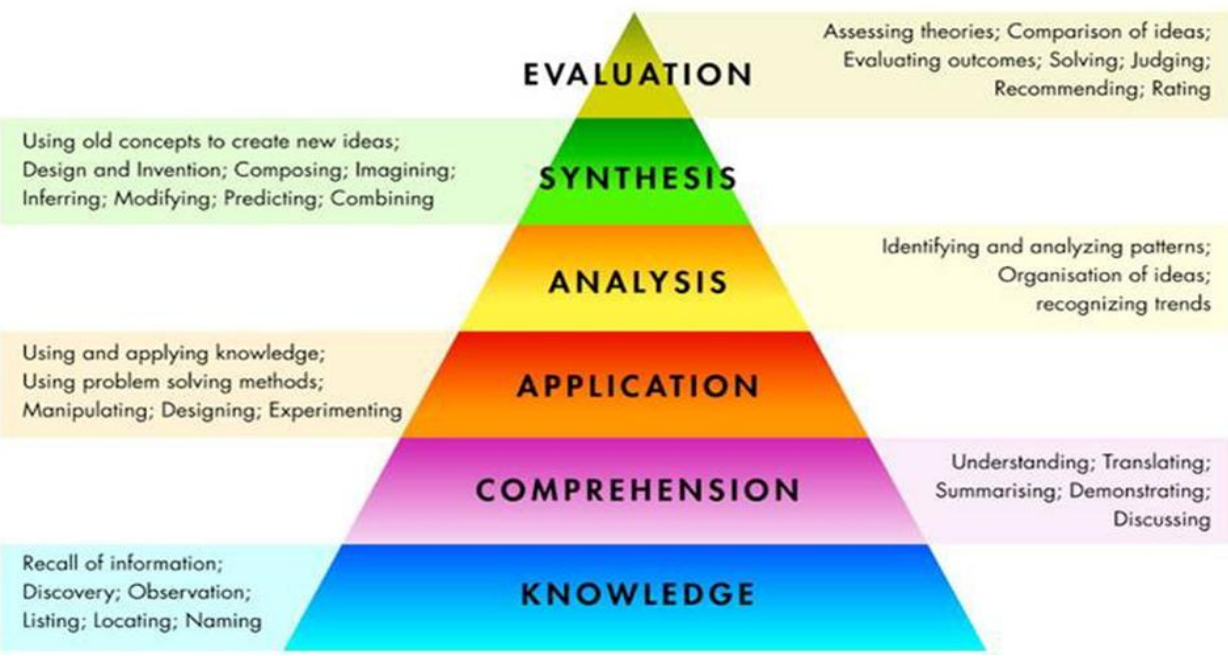

Figure 3. Bloom's Taxonomy Pyramid.

We have chosen a scoring approach ranging from one to six. The adopted system is the following:

- Criterion integrating the "knowledge" level: one point.

- Criterion integrating the "understanding" level: two points.

- Criterion integrating the "application" level: three points.

- Criterion integrating the "analysis" level: four points.

- Criterion integrating the "synthesis" level: five points.

- Criterion integrating the "evaluation" level: six points.

According to the definition given by each accreditation body, the learning outcome may have a score ranging from one to six points. 
For example, for the Knowledge Outcomes, EA determines the learning outcomes as follows: "knowledge and understanding of mathematics, sciences, engineering sciences and technologies underpinning their engineering branch."

It can be noticeable that the organization demands that students "know" and "understand" mathematics, sciences ... so the mark awarded will be "two points." It corresponds to the highest level stipulated in the learning outcome's explanation which is "understand."

The same procedure was followed for all learning outcomes. Each of the four criteria, knowledge outcomes, learned abilities, affective outcomes or skill outcomes, was scored according to the level required by the accreditation bodies.

If any of the four criteria contains many learning outcomes, the grade received means the average of the marks obtained.

The Bayes grid was then realized, for that the certification organizations have been arranged in columns and the selection indicator in line.

The table below shows the results of the study.

Table 4. Bayes matrix

\begin{tabular}{ccccccc}
\hline $\begin{array}{c}\text { Criterion/ } \\
\text { Organization }\end{array}$ & $A B E T$ & EUR-ACE & EA & JABEE & ABEEK & CEAB \\
\hline Knowledge Outcomes & 3.00 & 3.25 & 2.00 & 3.00 & 3.00 & 3.50 \\
Learned Abilities & 4.33 & 4.19 & 4.33 & 4.00 & 4.17 & 4.00 \\
Skills Outcomes & 4.28 & 4.50 & 4.67 & 4.50 & 4.25 & 4.67 \\
Affective outcomes & 1.50 & 2.50 & 2.00 & 2.00 & 2.00 & 3.00 \\
Total & 13.11 & 14.44 & 13.00 & 13.50 & 13.42 & 15.17 \\
\hline
\end{tabular}

After knowledge outcomes, learned abilities, affective outcomes or skill outcomes integration's analysis, it was possible to identify that the ratings of the organizations seem very close, with a slight advance for the Canadian and European ones. What was concluded then is that the CEAB and EUR-ACE have the most complete and demanding list of learning outcomes.

For Morocco, the examination of both the national booklet and the ENSEM's engineering training accreditation showed that learning outcomes are unclearly determined. The various module managers specify the objectives for each unit and the prerequisites to have. However, these definitions remain brief and aren't always communicated to students. It was therefore decided to compare the CMPI branch syllabus with the learning outcomes of European certification body.

\section{Study of Training Programs Related to CMPI Branch at ENSEM}

The objective of this analysis is to review the expectations of the CMPI training about learning outcomes at ENSEM.

The benchmarking helped selecting Canadian and European organizations lists as the most exhaustive in terms of learning outcomes.

Since engineering education systems in Europe and Morocco represent similarities, the EUR-ACE Framework Standards (EAFS) was opted for as a reference for this study.

Currently, the competency framework and the learning outcomes index don't exist at ENSEM. However, the accreditation reports specify the expectations and objectives of the modules and the programs.

Then, we considered the CMPI syllabus for 2015 (amendment 2018) and compared it to the various learning outcomes proposed by EUR-ACE (G.Augusti \& al., 2011).

The EUR-ACE Framework Standards (EAFS) define 23 learning outcomes for the second cycle that are grouped into six categories:

- Knowledge and Understanding;

- Engineering Analysis;

- Engineering Design;

- Investigations; 
- Engineering Practice;

- Transferable (personal) Skills.

The table below represents the number of units in the CMPI program that meet at least one concept required by the EAFS.

Table 5. Comparison between the EAFS and the CMPI modules objectives at ENSEM

\begin{tabular}{|c|c|c|c|}
\hline$N^{\circ}$ & $\begin{array}{l}\text { Category of the } \\
\text { EAFS }\end{array}$ & Description & $\begin{array}{l}\text { Number of modules } \\
\text { including the EAFS }\end{array}$ \\
\hline 1 & $\begin{array}{l}\text { Knowledge and } \\
\text { Understanding }\end{array}$ & $\begin{array}{l}\text {-An in-depth knowledge and understanding of their engineering } \\
\text { branch principles }\end{array}$ & 24 \\
\hline 2 & & -A critical awareness of their branch forefront & 1 \\
\hline 3 & $\begin{array}{l}\text { Engineering } \\
\text { Analysis }\end{array}$ & $\begin{array}{l}\text {-The ability to solve unfamiliar and incompletely defined } \\
\text { problems with competing specifications }\end{array}$ & 2 \\
\hline 4 & & $\begin{array}{c}\text {-The ability to formulate and solve problems in new and } \\
\text { emerging areas of their specialization }\end{array}$ & 3 \\
\hline 5 & & $\begin{array}{l}\text {-The ability to use their knowledge and understanding to } \\
\text { conceptualize engineering models, systems and processes }\end{array}$ & 10 \\
\hline 6 & & -The ability to apply innovative methods in problem solving & 1 \\
\hline 7 & $\begin{array}{l}\text { Engineering } \\
\text { Design }\end{array}$ & $\begin{array}{c}\text {-An ability to use their knowledge and understanding to design } \\
\text { solutions to unfamiliar problems, possibly involving other } \\
\text { disciplines }\end{array}$ & 10 \\
\hline 8 & & $\begin{array}{l}\text {-An ability to use creativity to develop new and original ideas and } \\
\text { methods }\end{array}$ & 1 \\
\hline 9 & & $\begin{array}{l}\text {-An ability to use their engineering judgment to work with } \\
\text { complexity technical uncertainty and incomplete information }\end{array}$ & 3 \\
\hline 10 & Investigations & -The ability to identify, locate and obtain required data & 0 \\
\hline 11 & & $\begin{array}{l}\text {-The ability to design and conduct analytic, modeling and } \\
\text { experimental investigations }\end{array}$ & 0 \\
\hline 12 & & -The ability of data critical evaluation and conclusions drawing & 0 \\
\hline 13 & & $\begin{array}{l}\text {-The ability to investigate the new and emerging technologies } \\
\text { application in their engineering branch }\end{array}$ & 0 \\
\hline 14 & $\begin{array}{l}\text { Engineering } \\
\text { Practice }\end{array}$ & $\begin{array}{l}\text {-The ability to integrate knowledge from different branches, and } \\
\text { handle complexity }\end{array}$ & 5 \\
\hline 15 & & $\begin{array}{l}\text {-A comprehensive understanding of applicable techniques and } \\
\text { methods, and of their limitations }\end{array}$ & 5 \\
\hline 16 & & $\begin{array}{c}\text {-Knowledge of the engineering practice non-technical } \\
\text { implications }\end{array}$ & 2 \\
\hline 17 & $\begin{array}{l}\text { Transferable } \\
\quad \text { Skills }\end{array}$ & $\begin{array}{l}\text {-Function effectively as an individual and as a member of a team } \\
\text { (at the more demanding level of the second cycle) }\end{array}$ & 3 \\
\hline 18 & & $\begin{array}{l}\text {-Use various methods to communicate effectively with the } \\
\text { engineering community and with society at broad (at the more } \\
\text { demanding level of the second cycle). }\end{array}$ & 7 \\
\hline 19 & & $\begin{array}{l}\text {-Demonstrate awareness of engineering practice health, safety } \\
\text { and legal issues, responsibilities and norms; the impact of } \\
\text { engineering solutions in a societal and environmental context, } \\
\text { and commit to professional ethics (at the more demanding level } \\
\text { of the second cycle). }\end{array}$ & $\begin{array}{l}2 \text { (health, safety, } \\
\text { environment) }\end{array}$ \\
\hline
\end{tabular}


20

21
-Demonstrate an awareness of project management and business

6 practices, such as risk and change management, and understand their limitations (at the more demanding level of the second cycle).

-Recognize the need for, and be able to engage in independent, lifelong learning (at the more demanding level of the second

cycle).

-Function effectively as different disciplines and levels team composed leaders

-Work and communicate effectively in national and international contexts
0

2

5

It is worth mentioning that a unit may include many learning outcomes.

It appears from this examination that EAFS number 10, 11, 12, 13 and 21 corresponding to investigation and lifelong learning aren't listed in any modules. It is also observed that for EAFS 19, the health, safety and environmental aspects are integrated in the syllabus unlike those relating to professionalism, ethics and equity.

However, some teachers at ENSEM use these EAFS but don't specify it in the accreditation description.

The analysis also demonstrated that the specifications don't use levels of skill acquisition detailed in Bloom's taxonomy (knowledge, understanding, application, analysis, synthesis and evaluation). Therefore, the descriptions define different paragraphs of the courses and represent only the notions that are taught in each subject.

Finally, in the examination conducted, it appears that even if the learning outcomes are unclearly determined for ENSEM training, several modules include one or more concepts required by the EAFS of the EUR-ACE label.

Knowing that to carry out this study on the learning assessment in Moroccan engineering schools and propose improvements, a Moroccan index of learning outcomes must be set up. Therefore, it is possible to draw inspiration from the EAFS list and adapt it to the Moroccan context.

\section{Conclusion}

The SWOT analysis of the CMPI branch accreditation at ENSEM allowed highlighting its strengths. Actually, it lies especially on its openness and partnerships with international operators and universities; the good structure of in-company training; the increase in the outgoing movement of students; the combination of traditional teaching methods and simulations by problem or project. English represents $6 \%$ of the program's hourly volume but it lasts insufficient because some engineering schools newly established in Morocco provide some of their disciplines in English.

The SWOT analysis served to detect and identify CMPI branch weaknesses. Indeed, it has no openness or partnership with research and instruction on innovation, business and enterprise creation, social responsibility, or ethics. Besides that, professional conduct remains limited. Teachers exclusively deliver the lessons. The development and monitoring of training don't rely on an evaluation of the sectors and/or trades expectations. Learning outcomes that students must acquire aren't determined nor defined in terms of knowledge or skills.

These strengths and weaknesses highlighted the threats that training may face in the future, notably, the non-recognition of diplomas at the international level or the inadequacy between education and labor market needs.

Through the accreditation analysis, opportunities that ENSEM teaching could benefit from were identified. In particular, proposing a Moroccan certification system that meets worldwide specifications and establishing a clear list of learning outcomes.

It's in this perspective that we conducted a benchmarking study of the different learning outcomes determined by foreign bodies. It allowed us to point out the Canadian and European organizations criteria as the most exhaustive and demanding.

This led us to the examination of the CMPI program at ENSEM with the European label EUR-ACE learning outcomes. This analysis shed light on we could highlight the connection between them and the objectives defined in Moroccan accreditation, focusing on non-integrated elements that should be introduced in Moroccan training.

Finally, to enhance the assessment in its engineering schools, the Moroccan certification system must use learning outcomes. The carried out examination results led to the conclusion that we can employ the European list by 
adapting it to the national need.

This production can serve as orientation and improvement to Moroccan accreditation. It helps to underline the absence of standards for the evaluation. Indeed, the syllabus doesn't specify the assessment methods, nor study them with companies. Additionally, they aren't founded on criteria that are defined in advance and publicly accessible.

The present paper suggests that a future study proposes a list of learning outcomes adapted to the Moroccan context. This study recommends a reliable evaluation system that reflects the true engineers levels by highlighting the skills acquired throughout the training which will allow the Moroccan engineering degree be internationally recognized.

\section{References}

Accreditation Board for Engineering Education of Korea. (2015). Criteria for accrediting Engineering programs. Retrieved from http://www.abeek.or.kr/appraisal/eac [Date of consultation: 15 November 2019].

Ahmed Ghouati (2010). The Bologna Process in the Maghreb. AIU Horizons, Association Internationale des Universités, 16, 20-22. hal-01585781.

Bernard Besson (2010). Méthodes d'analyse appliquées à l'intelligence économique. France. Poitiers University: Institute of Communication.

Commission des Titres d'Ingénieur (2019). Références et orientations de la Commission des titres d'ingénieurs: références et critères d'accréditation, Livre 1. France : Commission des Titres d'Ingénieur.

Commission nationale de Coordination de l'Enseignement supérieur [CNACES] (2014). Cahier des normes pédagogiques nationales du cycle ingénieur. Maroc : Commission nationale de Coordination de l'Enseignement supérieur

Communauté française (2013). Décret du 7 novembre 2013 définissant le paysage de l'enseignement supérieur et l'organisation académique des études. Chapter IV, art. 15.

Dominique LEMENU \& Elfriede HEINEN (2015). Comment passer des compétences à l'évaluation des acquis des étudiants? Édition de boek. Louvain-la-Neuve, Belgique.

Dr Paideia (2018). Misusing Bloom's Taxonomy. Retrieved from: https://medium.com/@dr.paideia2020/misusing-blooms-taxonomy-f570c5f56c2a [date of consultation: 2 August 2019].

École Nationale Supérieure d’Électricité et de Mécanique (2007, 2011, 2015, 2018). Certification Documents, Internal documents. Morocco: École Nationale Supérieure d'Électricité et de Mécanique.

Engineering Accreditation Commission (2014). Criteria for accrediting engineering programs. U.S.A.: Accreditation Board for Engineering and technology.

Engineers Australia (n.d.). Stage 1 Competency Standard for Professional Engineer. Australia: Engineers Australia.

Engineers Canada (2015). Accreditation Criteria and Procedures. Canada.

EUGENE Academic Network (n.d.). Comparison of EUR-ACE and International Engineering Alliance Standards improve transnational mobility of engineering students, graduates and professionals, deliverable number 26 of Work Package 8 of Line C. European Commission.

The Bologna Process and the European Higher Education Area. Retrieved from: https://ec.europa.eu/education/policies/higher-education/bologna-process-and-european-higher-education-area en [date of consultation: September 2019]

Fourmental, W. (n.d.). Les outils de décision. Retrieved from: http://eduscol.education.fr/sti/sites/eduscol.education.fr.sti/files/ressources/techniques/1396/1396-172-p82.pdf [date of consultation: January 3, 2016]

G. Augusti \& Al. (2011). EUR-ACE: A System of Accreditation of Engineering Programmes Allowing National Variants, Madrid. [PDF] Retrieved from: https://www.enaee.eu/wp-content/uploads/2018/11/3a1985abb40303f6b471a1466c85967e1.pdf [Date of consultation: September 2019]

International Assembly for collegiate business education (2014-2016). Bloom's taxonomy of Educational Objectives and writing Intended Learning Outcomes Statements. Lenexa, Kansas, U.S.A.: International Assembly for collegiate business Education. 
International Engineering Alliance (n.d.) Sydney Accord. Retrieved from: https://www.ieagreements.org/accords/sydney/ [date of consultation: September 2019]

International Engineering Alliance (n.d.). Washington Accord. Retrieved from: https://www.ieagreements.org/accords/washington/ [date of consultation: September 2019]

Isabelle Senécal (2016). Comment donner une rétroaction efficace aux étudiants ? Collège Sainte-Anne. Retrieved from: https://www.profweb.ca/publications/articles/comment-donner-une-retroaction-efficace-aux-etudiants.

Japan Accreditation Board for Engineering Education (2015). JABEE Criteria Guide for accreditation of Engineering Education Programs at Bachelor Level. Tokyo: Japan Accreditation Board for Engineering Education.

Paris South University (n.d.) SWOT Analysis. Retrieved from: https://www.u-psud.fr/_resources/scd/scd-Sceaux/swot.pdf?download=true [date of consultation: 10 August 2017]

Peter T. Well (2001). Accreditation and Student Learning Outcomes: A Proposed Point of Departure. U.S.A.: Council for Higher Education Accreditation, CHEA Occasional Paper.

Sanae El Ouahabi \& Ahmed Bousselhami (2018). Analyse économique du secteur industriel au Maroc. European Scientific Journal, March 2018 Edition, 14(7). https://doi.org/10.19044/esj.2018.v14n7p168 